\title{
Correlation of Serum Tissue Transglutaminase Antibody Levels and Marsh Grading of Duodenal Biopsy in Patients of Celiac Disease
}

\author{
Benjith Paul*, Prateek Kinra, Bhaskar Nandi and AS Prasad \\ Department of Pathology and Internal Medicine, Command Hospital Air Force, Bangalore, India
}

\begin{abstract}
Background: Celiac disease (CD) is a chronic small intestinal immune-mediated enteropathy precipitated in genetically predisposed individuals by ingestion of wheat gluten and related proteins of barley and rye. It is an under-diagnosed gluten-sensitive enteropathy, usually presenting with atypical/extra-intestinal features. Duodenal biopsy is considered as the gold standard in the diagnosis of CD. Serum anti tissue transglutaminase (anti-tTG) antibodies isauto antibodies directed against tissue transglutaminase (tTG) enzyme.Aims and objective: The aim of the study is to find out the prevalence of CD among clinically suspected cases of malabsorption, to assess the correlation of anti-tTG levels with modified Marsh grading of duodenal biopsy, to find out sensitivity, specificity and predictive values of anti-tTG test and to calculate the cut off values of anti-tTG diagnostic of high grade CD.

Methodology: The present study included 118 clinically suspected patients of malabsorption in which both duodenal biopsy and anti-tTG test was done. The mucosal damage graded according to the modified Marsh grading and anti-tTG tests were done in serum using ELISA kit.

Results: The prevalence of CD among clinically suspected cases of malabsorption was $12.7 \%$. The incidence was highest in middle aged male patients. The most common clinical symptom was chronic diarrhea and commonest presenting sign was anemia. Anti-tTG levels were found to be proportionately increasing with the severity of $\mathrm{CD}$ and showed a positive correlation( $\mathrm{r}=0.433)$. Patients with anemia and chronic diarrhea showed statistically significant ( $\mathrm{p}$ value $=0.0242$ and 0.0089 respectively) mean anti-tTG levels in Celiac patients in relation to non-Celiac patients. Although the mean levels of anti-tTG was 6.3 times higher than baseline in grade 3 disease, the ROC analysis showed that anti-tTG in isolation had no significance in exactly grading the disease ( $\mathrm{AUC}=0.30$ ).

Conclusion: Positive correlation was found between anti-tTG levels and modified Marsh grading. Anti-tTG showed proportionate increase with severity of duodenal damage.Anti-tTG test showed low sensitivity $(42.86 \%)$ and high specificity $(84.34 \%)$. Hence it is not a reliable tool in isolation to screen $\mathrm{CD}$ but should be used in combination with duodenal biopsy. It can be used to assess the severity of CD and for follow up.
\end{abstract}

\section{Keywords: Malabsorption, Celiac Disease (CD), Duodenal Biopsy, Modified Marsh Grading, Serum Anti Tissue Transglutaminase (anti-tTG) Test.}

\section{Introduction}

Malabsorption is a disease condition characterized by defective absorption of fats, proteins, carbohydrates, fat and water-soluble vitamins, electrolytes and minerals. Celiac disease is considered as one of the most common causes of malabsorption. ${ }^{[1]}$

In 2013 Oslo defined Celiac diseases as a chronic small intestinal immune-mediated enteropathy precipitated in genetically predisposed individuals by exposure to dietary gluten ${ }^{[2]}$ Celiac disease (CD), also called as gluten-sensitive enteropathy, endemic sprue and non-tropical sprue. It is an autoimmune disorder triggered by the ingestion of wheat gluten and related proteins of barley and rye in genetically susceptible adults and children. ${ }^{[3]}$ Well-identified haplotypes in the human leukocyte antigen (HLA) class II region like HLA-DQ8 and HLA-DQ2 confer genetic susceptibility. ${ }^{[4]}$
The risk of having Celiac disease is high in first-degree relatives $(10 \%)$ and in second-degree relatives (5\%), as well in people with autoimmune diseases, diabetes, Down's syndrome and a number of other associated diseases. ${ }^{[5]}$

Adefinite diagnosis of Celiac disease is based on histological changes, including intraepithelial lymphocytosis, crypt hyperplasia, and varying degrees of villous atrophy, graded according to a classification system proposed by Marsh in 1992 and now widely used as modified Marsh grading depicted in table $1 .{ }^{[6-9]}$

Duodenal biopsy remains the gold standard for diagnosis of $\mathrm{CD}$, even though there are very specific serologic tests like anti-gluten and anti-tissue transglutaminase (antitTG) antibodies. Correlation of clinical, serologic, and histological features is essential for the definitive diagnosis of this condition. ${ }^{[10]}$ 
Table 1: Modified Marsh grading of histological findings in Celiac disease.

\begin{tabular}{|c|c|c|c|}
\hline Marsh Type & $\begin{array}{c}\text { Intraepithelial lymphocytes(IELs) / } \mathbf{1 0 0} \\
\text { enterocytes - duodenum }\end{array}$ & Crypt hyperplasia & Appearance- Villi \\
\hline 0 & $<30$ & Normal & Normal \\
\hline 1 & $>30$ & Normal & Normal \\
\hline 2 & $>30$ & Increased & Normal \\
\hline $3 a$ & $>30$ & Increased & Mild atrophy \\
\hline $3 b$ & $>30$ & Increased & Marked atrophy \\
\hline $3 c$ & $>30$ & Increased & Complete atrophy \\
\hline
\end{tabular}

\section{Material and Methods}

This is a prospective descriptive study. Duodenal biopsy and serum samples from 118 patients of clinically suspected malabsorption were studied over a period of 32 months from 01 Jan 2014 to 31 Aug 2016. Firstly, the duodenal biopsies sent in cases of clinically suspected malabsorption was processed using standard FFPE (Formalin Fixed and Paraffin Embedded) method and HPE. Sections were stained by H\&E and examined under microscope, graded according to the modified Marsh grading. In these patients blood $(5 \mathrm{ml})$ was collected in sterile vacutainer and tested for anti-tTG antibody levels (using standard ELISA technique). Anti tTG levels $\geq 7 \mathrm{U} / \mathrm{ml}$ were taken as positive.

All clinically diagnosed cases of malabsorption presenting with features of chronic diarrhea, anemia, chronic fatigue, weight loss, abdominal distension, chronic abdominal pain etc., and requiring further investigation was included in this study. Duodenal biopsies taken from patients with no features suggestive of malabsorption were excluded. Also in cases of duodenal biopsy showing parasites, Non Hodgkin Lymphoma (NHL) and periampullary carcinoma was excluded.

Correlation between Modified Marsh grading and IgA antitTG in Celiac disease has been analyzed using Pearson product- moment correlation coefficient or correlation coefficient (r). The correlation of clinical signs/symptoms with grade of disease was also determined using correlation coefficient ( $r$ ). The positive predictive value, negative predictive value, sensitivity and specificity of anti-tTG have been calculated using Marsh grading on biopsy as the gold standard. The statistical significance of presence/absence of the clinical findings against presence / absence of CD was tested using Fishers 2 tailed exact $t$ test to find out the 'p' value. Unpaired t test was used to calculate the difference of means of anti-tTG between biopsy positive and negative cases using standard deviation (SD). Any $\mathrm{p}$ value below 0.05 was considered significant. The cut offs of anti-tTG in various grades of $\mathrm{CD}$ was attempted to be calculated using receiver operating characteristic (ROC) curve.

\section{Results}

217 clinically suspected cases of malabsorption underwent endoscopic duodenal biopsy in our institute during the period from 01 Jan 2014 - 31 Aug 2016 (32 months). Out of these 217 cases, 118 cases also underwent testing of serum anti tissue transglutaminase (anti-tTG) levels. As duodenal biopsy remains the gold standard, out of the 118 cases 35 cases showed histological features of Celiac disease.

In our study the prevalence of Celiac disease among clinically suspected cases of malabsorption $(n=217)$ with biopsy positivity as per modified marsh grading was found to be $24 \%$. The prevalence of Celiac disease among clinically suspected cases of malabsorption with positive anti-tTG positive levels was found to be $23 \%$. In cases with both biopsy positivity and positive anti-tTG levels was found to be $12.7 \%$. The prevalence among population under the medical cover of our hospital $(n=2,10,600)$ was found to be $0.04 \%$.

Majority of positive cases were found to be middle aged patients with mean age of presentation $36.6 \pm 15.3$ yrs. The gender distribution in our study is $23(74 \%)$ males and 8 $(26 \%)$ females. The chief presenting clinical findings in our study were anemia $22(63 \%)$, followed by chronic diarrhoea 05(14\%), weight loss 05(14\%), dyspepsia 02(6\%), and short stature 01(3\%).

Among the 118 cases of clinically suspected cases of malabsorption in which both biopsy and serum anti-tTG levels were compared, 83 cases were found to be Marsh grade 0 or normal cases as per duodenal biopsy. Out of the 35 duodenal biopsy positive cases 22 (63\%) cases belong to Marsh grade I, 02 (6\%) cases were Marsh grade II, 6 (17\%) cases were Marsh grade IIIA, 4 (11\%) cases belong to Marsh Grade IIIB and 01 (3\%) case belong to Marsh grade IIIC. The findings are depicted in Fig No. 1

When we compared duodenal biopsy positive cases with serum anti-tTG levels, only 15 cases were found to have raised serum levels, which gave a sensitivity of $42.86 \%$ and specificity of $84.34 \%$. The positive predictive value 
(PPV) and negative predictive value (NPV) of the test was found to be $53.57 \%$ and $77.78 \%$ respectively (Table 2). In our study we also found 13 cases with positive serum tissue transglutaminase and negative duodenal biopsy (false positive) and 20 cases with normal serum tissue transglutaminase and positive duodenal biopsy (false negative).

On comparing mean serum anti-tTG levels with different grades of modified Marsh grading it showed an increasing trend from grade 0 to grade III. Grade 0 cases with average value of $4.85 \mathrm{U} / \mathrm{ml}$, Grade I - $18.86 \mathrm{U} / \mathrm{ml}$, Grade II 21.75U/ml and Grade III with 30.50/ml (Table $3 \&$ Figure 2). The correlation coefficient [Pearson product- moment correlation coefficient (PMCC)] between the increasing TTG level and corresponding grade of disease gave an ' $r$ ' value of 0.433 , which is more than 0 which means there is positive correlation between serum tissue transglutaminase antibody levels and progressive Marsh grading of duodenal biopsyin patients of Celiac disease.

We attempted to find out the cut off values of anti-tTG in high grades of CD using ROC curve. Although the mean levels of anti-tTG was 6.3 times higher than baseline in grade 3 disease (mean baseline level $=4.85 \mathrm{U} / \mathrm{ml}$, mean grade 3 level $=30.5 \mathrm{U} / \mathrm{ml}$ ), the ROC analysis showed that anti-TTG in isolation had no significance in exactly grading the disease ( $\mathrm{AUC}=0.30$ ). Any $\mathrm{AUC}<0.60$ is a failed cut off level threshold. Hence no exact cut off to diagnose grade 3 disease is possible (Figure 3).

On correlating the clinical signs/symptoms of the index cases with grades of disease it was found that there was a positive correlation between increasing grade of disease with weight loss $(r=0.664)$, dyspepsia $(r=0.664)$ and short stature $\mathrm{r}=0.393$ ). On the contrary there was no correlation of grade of disease with presence/absence of anemia $(r=$ $-0.193)$ and chronic diarrhea $(r=-0.70)$ (Table 4).

We divided our study population into two groups based on histopathological findings into (i) CD positive, (ii) CD negative using Marsh grading. Further we tested the statistical significance using Fishers exact $t$ test of presence/absence all the five main clinical findings against presence / absence of CD. The tests showed no statistical significant difference in these two groups. The $\mathrm{p}$ values for the different findings are anemia $(p=0.380)$, chronic diarrhoea $(p=0.860)$, weight loss $(p=0.2986)$, dyspepsia $(p=0.850)$ and short stature $(p=0.296)$. Hence none of the clinical findings in isolation are diagnostic of CD.

We went ahead and compared the mean levels of anti-tTG in patients having positive signs and symptoms against the presence / absence of Celiac disease. On calculating the difference of means using unpaired ' $t$ ' test between biopsy positive and negative cases significant $p$ value was obtained with anemia $(p=0.0242)$ and chronic diarrhoea $(p=0.0089)$ whereas insignificant $p$ value was obtained with weight loss $(p=0.524)$ and dyspepsia $(p=0.4926)$. Statistical test could not be applied for short stature as only one case had the same as main clinical finding. It can be construed that mean tTG levels are higher in patients of Celiac disease when following symptoms are present: anemia and chronic diarrhea (Table 5\&6).

Table 2: Sensitivity, specificity, PPV and NPV of serum tissue transglutaminase (anti-tTG) versus duodenal biopsy graded as per Modified Marsh grading.

\begin{tabular}{|c|c|c|c|}
\hline Statistic & Formula & Value & $95 \% \mathrm{Cl}$ \\
\hline Sensitivity & $\frac{a}{a+b}$ & $42.86 \%$ & $26.32 \%$ to $60.65 \%$ \\
\hline Specificity & $\frac{d}{c+d}$ & $84.34 \%$ & $74.71 \%$ to $91.39 \%$ \\
\hline Positive Predictive Value & $\frac{a}{a+c}$ & $53.57 \%\left(^{*}\right)$ & $33.87 \%$ to $72.49 \%$ \\
\hline Negative Predictive Value & $\frac{d}{b+d}$ & $77.78 \%\left(^{*}\right)$ & $67.79 \%$ to $85.87 \%$ \\
\hline
\end{tabular}


Table 3: Average and median values of serum anti-tTG in positive cases as per biopsy.

\begin{tabular}{|c|c|c|c|c|}
\hline Modified Marsh Grading & $\begin{array}{c}\text { Number of } \\
\text { cases }\end{array}$ & $\begin{array}{c}\text { Average value of serum } \\
\text { anti-tTG (U/mI) }\end{array}$ & SD & $\begin{array}{c}\text { Median of serum anti-tTG } \\
\text { (U/ml) values }\end{array}$ \\
\hline Marsh Grade 0 & 83 & 4.85 & \pm 5.71 & 3.02 \\
\hline Marsh Grade - I & 22 & 18.86 & \pm 45.68 & 4.80 \\
\hline Marsh Grade - II & 02 & 21.75 & \pm 30.75 & 21.75 \\
\hline Marsh Grade - III & 11 & 30.50 & \pm 57.13 & 3.55 \\
\hline
\end{tabular}

Table 4: Correlation of Clinical findings with modified Marsh grading gradient in Celiac patients.

\begin{tabular}{|c|c|c|c|c|c|c|}
\hline $\begin{array}{l}\text { Modified Marsh } \\
\text { Grading }\end{array}$ & $\begin{array}{l}\text { Total no of } \\
\text { cases- } 118 \\
\text { ( \% of cases) }\end{array}$ & $\begin{array}{l}\begin{array}{c}\text { No. of anemia } \\
\text { cases } \\
\text { ( } \% \text { Of positive } \\
\text { cases) }\end{array} \\
\end{array}$ & $\begin{array}{c}\text { No. of chronic } \\
\text { diarrhoea } \\
\text { cases ( } \% \text { of } \\
\text { positive cases) }\end{array}$ & $\begin{array}{l}\text { No. of weight } \\
\text { loss cases } \\
\text { ( } \% \text { of positive } \\
\text { cases) }\end{array}$ & $\begin{array}{c}\text { No. of } \\
\text { dyspepsia } \\
\text { cases ( } \% \text { of } \\
\text { positive cases) }\end{array}$ & $\begin{array}{c}\text { No. of short } \\
\text { stature cases } \\
\text { ( } \% \text { of positive } \\
\text { cases) }\end{array}$ \\
\hline $\begin{array}{c}\text { Marsh } \\
\text { Grade } 0 \text { / Normal }\end{array}$ & $\begin{array}{c}83 \\
(70 \%)\end{array}$ & $\begin{array}{c}60 \\
(72 \%) \\
\end{array}$ & \begin{tabular}{|c|}
13 \\
$(16 \%)$ \\
\end{tabular} & $\begin{array}{c}06 \\
(7 \%) \\
\end{array}$ & \begin{tabular}{|c|}
04 \\
$(5 \%)$ \\
\end{tabular} & $\begin{array}{c}00 \\
(0 \%)\end{array}$ \\
\hline Marsh Grade - I & $\begin{array}{c}22 \\
(19 \%) \\
\end{array}$ & $\begin{array}{c}16 \\
(72 \%) \\
\end{array}$ & $\begin{array}{c}03 \\
(14 \%) \\
\end{array}$ & $\begin{array}{c}03 \\
(14 \%) \\
\end{array}$ & $\begin{array}{c}00 \\
(0 \%)\end{array}$ & $\begin{array}{c}00 \\
(0 \%) \\
\end{array}$ \\
\hline Marsh Grade -II & $\begin{array}{c}02 \\
(2 \%) \\
\end{array}$ & $\begin{array}{c}00 \\
(0 \%) \\
\end{array}$ & $\begin{array}{c}00 \\
(0 \%)\end{array}$ & $\begin{array}{c}02 \\
(100 \%)\end{array}$ & $\begin{array}{c}00 \\
(0 \%)\end{array}$ & $\begin{array}{c}00 \\
(0 \%)\end{array}$ \\
\hline Marsh Grade - Illa & $\begin{array}{c}06 \\
(5 \%) \\
\end{array}$ & $\begin{array}{c}04 \\
(66 \%)\end{array}$ & $\begin{array}{c}01 \\
(17 \%)\end{array}$ & $\begin{array}{c}00 \\
(0 \%)\end{array}$ & $\begin{array}{c}01 \\
(17 \%)\end{array}$ & $\begin{array}{c}00 \\
(0 \%)\end{array}$ \\
\hline Marsh Grade - IIlb & $\begin{array}{c}04 \\
(3 \%)\end{array}$ & $\begin{array}{c}02 \\
(50 \%) \\
\end{array}$ & $\begin{array}{c}01 \\
(25 \%) \\
\end{array}$ & $\begin{array}{c}00 \\
(0 \%)\end{array}$ & $\begin{array}{c}00 \\
(0 \%)\end{array}$ & $\begin{array}{c}01 \\
(25 \%) \\
\end{array}$ \\
\hline Marsh Grade - IIIc & $\begin{array}{c}01 \\
(1 \%) \\
\end{array}$ & $\begin{array}{c}00 \\
(0 \%) \\
\end{array}$ & $\begin{array}{c}00 \\
(0 \%)\end{array}$ & $\begin{array}{c}00 \\
(0 \%) \\
\end{array}$ & $\begin{array}{c}01 \\
(100 \%) \\
\end{array}$ & $\begin{array}{c}00 \\
(0 \%) \\
\end{array}$ \\
\hline r value & -0.557 & -0.193 & -0.70 & 0.664 & 0.664 & 0.3927 \\
\hline
\end{tabular}

Table 5: Correlation of anemia and mean anti-tTG levels with presence/absence of Celiac disease.

\begin{tabular}{|c|c|c|c|c|c|c|}
\hline $\begin{array}{c}\text { Modified } \\
\text { Marsh Grading }\end{array}$ & $\begin{array}{c}\text { Total no of } \\
\text { cases- 118 } \\
\text { (\% of cases) }\end{array}$ & $\begin{array}{c}\text { No of anemia } \\
\text { cases (\% Of } \\
\text { positive cases) }\end{array}$ & $\begin{array}{c}\text { Average anti- } \\
\text { tTG values of } \\
\text { positive cases }\end{array}$ & $\begin{array}{c}\text { Standard } \\
\text { deviation }\end{array}$ & $\begin{array}{c}\text { No of cases with } \\
\text { no anemia ( \% Of } \\
\text { cases) }\end{array}$ & $\begin{array}{c}\text { Average anti- } \\
\text { tTG values of } \\
\text { negative cases }\end{array}$ \\
\hline $\begin{array}{c}\text { Marsh Grade } \mathbf{0} \\
\text { / Normal }\end{array}$ & $\begin{array}{c}83 \\
(70 \%)\end{array}$ & $\begin{array}{c}60 \\
(72 \%)\end{array}$ & 4.64 & \pm 5.63 & 23 \\
$(28 \%)$ & 13 \\
\hline $\begin{array}{c}\text { Cases } \\
\text { with Marsh } \\
\text { Grade1-3 }\end{array}$ & $\begin{array}{c}22 \\
(30 \%)\end{array}$ & 14.36 & \pm 32.52 & $(37 \%)$ & 35.91 \\
\hline Fishers 2 tailed exact test for analysing the statistical significance of anemia vs presence/absence of \\
disease
\end{tabular}

Table 6: Correlation of chronic diarrhoea and mean anti-tTG levels with presence/absence of Celiac patients.

\begin{tabular}{|c|c|c|c|c|c|c|}
\hline Modified Marsh Grading & $\begin{array}{c}\text { Total no } \\
\text { of cases- } \\
118 \text { ( } \% \text { of } \\
\text { case) }\end{array}$ & $\begin{array}{c}\text { No of chronic } \\
\text { diarrhoea cases } \\
\text { ( } \% \text { of positive } \\
\text { cases) }\end{array}$ & $\begin{array}{c}\text { Average anti- } \\
\text { tTG values } \\
\text { of positive } \\
\text { cases }\end{array}$ & $\begin{array}{l}\text { Standard } \\
\text { deviation }\end{array}$ & $\begin{array}{c}\text { No of cases } \\
\text { with no chronic } \\
\text { diarrhoea } \\
\text { ( } \% \text { of cases) }\end{array}$ & $\begin{array}{c}\text { Average anti- } \\
\text { tTG values } \\
\text { of negative } \\
\text { cases }\end{array}$ \\
\hline $\begin{array}{c}\text { Marsh } \\
\text { Grade } 0 \text { / Normal }\end{array}$ & $\begin{array}{c}83 \\
(70 \%) \\
\end{array}$ & $\begin{array}{c}13 \\
(16 \%) \\
\end{array}$ & 4.64 & \pm 6.37 & $\begin{array}{c}70 \\
(84 \%) \\
\end{array}$ & 5.40 \\
\hline $\begin{array}{c}\text { Cases with Marsh Grade } \\
1-3\end{array}$ & $\begin{array}{c}35 \\
(30 \%)\end{array}$ & $\begin{array}{c}05 \\
(14 \%)\end{array}$ & 79.56 & \pm 94.24 & $\begin{array}{c}30 \\
(86 \%)\end{array}$ & 34.92 \\
\hline \multicolumn{6}{|c|}{$\begin{array}{c}\text { Fishers } 2 \text { tailed exact t test for analysing the statistical significance of presence of chronic diarrhoea vs } \\
\text { presence/absence of disease }\end{array}$} & $\begin{array}{c}\mathrm{P}=0.860 \\
\text { (insignificant) }\end{array}$ \\
\hline \multicolumn{6}{|c|}{ Unpaired t test to calculate the difference of means using SD } & $\begin{array}{c}\mathrm{P}=0.0089 \\
\text { (significant) }\end{array}$ \\
\hline
\end{tabular}




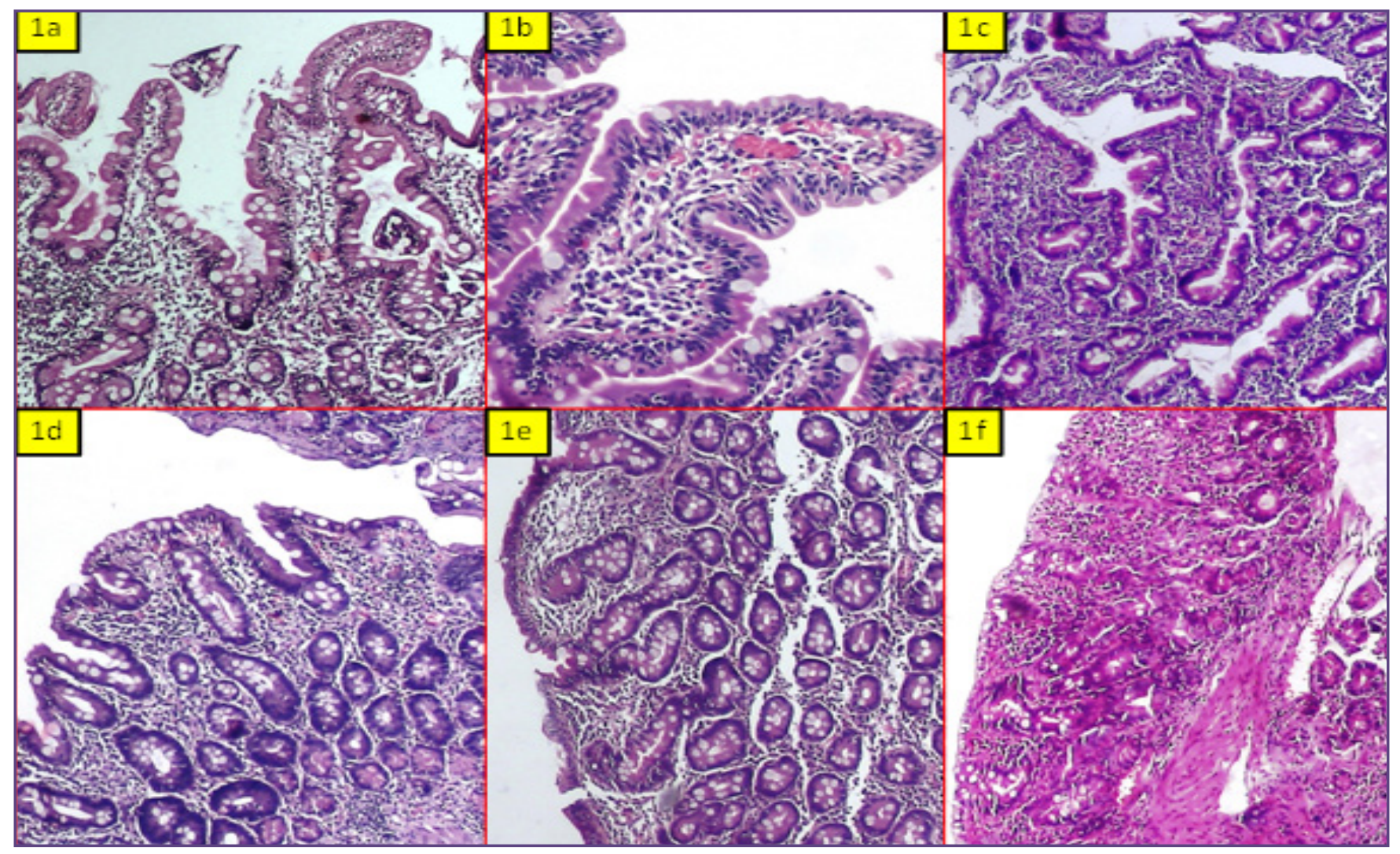

Fig. 1:a. Duodenal biopsy showing normal histomorphology, H\&E 40x; b. Duodenal biopsy showing modified Marsh grade I lesion with increased intraepithelial lymphocytes (IELs), H\&E 40X; c. Duodenal biopsy showing modified Marsh grade II lesion with crypt hyperplasia along with grade I features, H\&E 40X; d. Duodenal biopsy showing modified Marsh Grade IIIa lesion, with mild villous atrophy and grade II features, H\&E 40X; e. Duodenal biopsy showing modified Marsh Grade IIIb lesion, with marked villous atrophy and grade II features, H\&E 40X; f. Duodenal biopsy showing modified Marsh Grade IIIc lesion, with complete villous atrophy and grade II features, H\&E 40X.

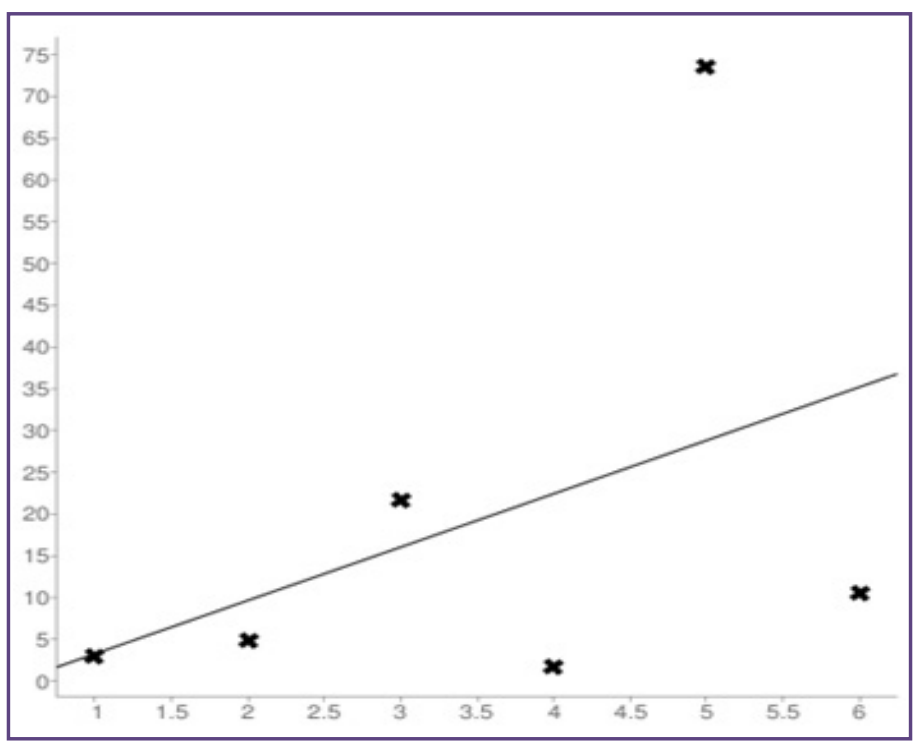

Fig. 2: Graph showing correlation coefficient(r)=0.433 between Median values of serum tissue transglutaminase (anti-tTG) and modified Marsh grading in positive cases as per duodenal biopsy. 


\section{ROC Curve for $y=0.5 \operatorname{Ln}(x)+0.79$ Area under curve $=0.3012$}

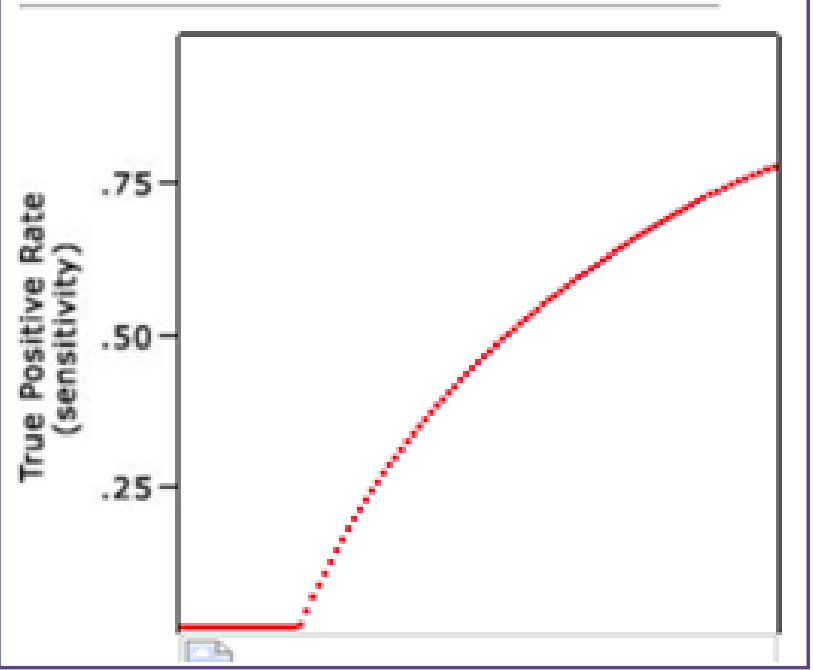

Fig. 3: The ROC curve of varied levels of anti-TG against the various grades of disease with $\mathrm{AUC}=0.30$.

\section{Discussion}

The prevalence of Celiac disease is globally $1 \%$, but large variations among different countries have been shown. ${ }^{[11]}$ The ratio of diagnosed versus undiagnosed cases in this condition is as high as 1:7. ${ }^{[12]}$ The prevalence in our dependent population of the hospital was $0.04 \%$. Celiac disease is an under-diagnosed condition and 'Celiac iceberg' is the term used to mention cases with atypical or extra-intestinal features of Celiac disease. Duodenal biopsy remains the gold standard for diagnosis of $\mathrm{CD}$. Anti-tissue transglutaminase (tTG) antibodies are auto antibodies of Celiac patients are directed against tissue transglutaminase (tTG) (an enzyme released from the intestine's cells when gluten passes into the mucosal layer) Correlation of clinical, serologic, and histological features is essential for the definitive diagnosis of this condition.

In our study the majority of positive cases were found to be middle aged patients with mean age of presentation $36.6 \pm 15.3$ yrs. Our findings with respect to the age distribution is similar to previous studies. ${ }^{[13,14]}$ The gender distribution in our study is $23(74 \%)$ males and $8(26 \%)$ females. Previous studies have female predominance. ${ }^{[13,}$ ${ }^{14,}{ }^{15}$ ] Predominant male population being treated in this service hospital can explain this discordance between our findings and other authors.

The chief presenting clinical findings in our study were anemia $22(63 \%)$, followed by chronic diarrhoea $05(14 \%)$, weight loss 05(14\%), dyspepsia 02(6\%), and short stature 01(3\%). Chronic diarrhoea was the most common presenting symptom and anemia was the most common non-gastrointestinal sign in concordance to previous studies. ${ }^{[13,14,16]}$

Among the 118 cases of clinically suspected cases of malabsorption in which both biopsy and serum anti-tTG levels were compared, 83 cases were found to be Marsh grade 0 or normal cases as per duodenal biopsy. Out of the 35 duodenal biopsy positive cases 22 (63\%) cases belong to Marsh grade I, 02 (6\%) cases were Marsh grade II, 6 $(17 \%)$ cases were Marsh grade IIIA, 4 (11\%) cases belong to Marsh Grade IIIB and 01(3\%) cases belong to Marsh grade IIIC. However, in the study by Kalhan et al on 226 patients, analysis of biopsy findings revealed maximum cases of grade $3 \mathrm{c}(n=137)$, followed by those of $3 \mathrm{~b}(n=$ $46)$ and $3 \mathrm{a}(n=30)$. Grades $1(\mathrm{n}=5), 2(\mathrm{n}=4)$ and grade 4 $(n=1) .{ }^{[14]}$ A study by Rahmati et al, maximum frequency of CD was seen in grade IIIa $55(34.6 \%)$, followed by grade IIIb 41 (25.8\%), grade IIIc 37 (23.2\%), grade I - $13(8.2 \%)$ and grade II - $13(8.2 \%) .{ }^{[13]}$ The predominance of grade I cases in our study can be explained by a low threshold of conducting a duodenal biopsy by our gastroenterology team. As a protocol, all chronic anemia patients are biopsied in our centre to rule out malabsorption syndromes.

When we compared duodenal biopsy positive cases with serum anti-tTG levels, only 15 cases were found to have raised serum levels, which give a sensitivity of $42.86 \%$ and specificity of $84.34 \%$. The positive predictive value (PPV) and negative predictive value (NPV) of the test was found to be $53.57 \%$ and $77.78 \%$ respectively. A study done by Emami et al, in Iran showed the overall sensitivity and specificity of anti-tTG antibody as 38\% and $98 \%$, respectively similar to our study. The positive and negative predictive values for the anti-tTG antibodies were $57 \%$ and $96 \%$, respectively. ${ }^{[17]}$ Our study showed a lower sensitivity as compared to other studies. ${ }^{[13,18,19]}$ However the specificity and negative predictive value were at par to most of international studies.[20] We assume that the false positive cases are due inability to get repeat biopsy samples and not cross checking with step section of the tissue block. Regarding false negative cases we assume that it is due to lack of availability of complete clinical history in cases of partially treated cases and cases other than Celiac disease with intraepithelial lymphocytes (IELs) and also with villous atrophy.

In our study an increasing trend in serum tissue transglutaminase antibody levels with higher grades of duodenal damage as per modified Marsh grading $(\mathrm{r}=0.433)$ has been seen in concordance to previous studies. ${ }^{[13-16,}$ 17, 21, 22] A study by Kalhan et al, 225 out of 226 patients 
studied showed raised anti-tTG levels and they also found a statistically significant increase in anti-tTG values from histologically milder forms of the disease to more severe forms $(P<0.001)$. Anti-tTG values in grades $3 \mathrm{c}+4$ were highest amongst all grades. ${ }^{[14]}$ Rahmati A et al, who studied 159 patients also showed an increasing trend of mean tTG antibody titres from normal duodenal histology to complete atrophy. ${ }^{[13]}$ Vivas S et al, who studied 97 children and 227 adults also found out that the mean tTG antibody levels showed a progressive increase with higher Marsh grades in both pediatric and adult age groups. The levels of tTG antibody were correlating significantly with Marsh types in the entire population $(r=0.661, P<0.0001)$, and separately for the pediatric $(r=0.633, P<0.001)$ and adult $(r=0.574$, $p<0.0001)$ groups. ${ }^{[21]}$

There was a positive correlation between increasing grade of disease with weight loss $(\mathrm{r}=0.664)$, dyspepsia $(\mathrm{r}=$ 0.664 ) and short stature $r=0.393$ ). On the contrary there was no correlation of grade of disease with presence/ absence of anemia $(r=-0.193)$ and chronic diarrhea $(r=$ -0.70 ). Hence we can conclude that weight loss, dyspepsia and short stature are more likely a clinical finding in the higher grade of the Celiac disease Bhattacharya et al, showed that the anthropometric parameters (weight and height $\mathrm{z}$ scores) correlated with titers as well as with the severity of the disease. Also emphasized on the severity of mucosal damage represented by the serological and histopathological markers and the consequent failure to thrive. ${ }^{[16]}$

\section{Conclusions}

The incidence of the Celiac disease in our study was high in the middle-aged patients and more in males than females. The most common presenting complaint was found to be chronic diarrhoea and most common extra-gastrointestinal sign was anaemia. Serum tissue transglutaminase levels were found to be proportionately increasing with the severity of Celiac disease and showed a positive correlation. A positive correlation between increasing grade of disease with weight loss, dyspepsia and short stature was also found. Patients with anemia and chronic diarrhea showed statistically significant high mean anti-tTG levels in Celiac patients in relation to non-Celiac patients. Serum tissue transglutaminase antibody test showed low sensitivity (42.86\%) and high specificity (84.34\%), also low positive predictive value $(53.57 \%)$ and high negative predictive value $(77.78 \%)$. Hence it is not a reliable tool in isolation to diagnose Celiac disease and should be conducted in combination with duodenal biopsy. It can also be used to assess the severity and do the follow up of the case.

\section{References}

1. Kumar V, Abbas A, Fausto N, Aster J. Robbins and Cotran pathologic basis of disease. 8th ed. Chapter 17, The gastrointestinal tract; p.793-94.

2. Kang JY, Kang AH, Green A, Gwee KA, Ho KY. Systematic review: worldwide variation in the frequency of coeliac disease and changes over time. Aliment PharmacolTher2013; 38: $226-45$.

3. Briani C, Samaroo D, Alaedini A. Celiac disease: From gluten to autoimmunity. Autoimmun Rev 2008; 7: 644-50.

4. Setty M, Hormaza L, Guandalini S. Celiac disease: Risk assessment, diagnosis, and monitoring. Mol DiagnTher 2008; 12:289-98.

5. Fasano A, Berti I, Gerarduzzi T, Not T, Colletti RB, Drago Set al. Prevalence of Celiac disease in at-risk and not-at-risk groups in the Unites States: a large multicenter study. Arch Intern Med 2003; 163: 286-92.

6. Green PH, Jabri B. Coeliac disease. Lancet 2003; 362: 383-91.

7. Ciclitira PJ, King AL, Fraser JS. AGA technical review on Celiac Sprue American Gastroenterological Association Gastroenterology. 2001;120: 1526-40.

8. Rostami K, Kerckhaert J, Tiemessen R, von Blomberg BM, Meijer JW, Mulder CJ. Sensitivity of antiendomysium and antigliadin antibodies in untreated Celiac disease: disappointing in clinical practice. Am J Gastroenterol1999; 94: 888-94.

9. Oberhuber G, Granditsch G. The histopathology of coeliac disease: time for a standardized report scheme for pathologists. Eur J GastroenterolHepatol 1999; 11: 1185-94.

10. Heredia PC, Castro PF. Adult Celiac disease. Rev Med Chil2007; 135:1186-94.

11. Lionetti E, Catasssi C. New clues in Celiac disease epidemiology, pathogenesis, clinical manifestations, and treatment.Int Rev Immunol 2011; 30: 219-31.

12. Tommasini A, Not $T$, Kiren V, Baldas V, Santon D. Mass screening for Celiac disease using antihuman transglutaminase antibody assay. Arch Dis Child 2004; 89:512-5.

13. Rahmati A, Shakeri R, Sohrabi MR, Alipour A, Boghratian $\mathrm{AH}$, Setareh $\mathrm{M}$ et al. Correlation of Tissue Transglutaminase Antibody with Duodenal Histologic Marsh Grading. Middle East J Dig Dis 2014; 6:131-6.

14. Kalhan S, Joseph P, Sharma S, Dubey S, Dudani S, Dixit M. Comparative study of histopathological Marsh grading with clinical and serological parameters in Celiac iceberg of north India. Indian J PatholMicrobiol 2011; 54:279-83.

15. Singh P, Kurray L, Agnihotri A, Das P, Verma AK, Sreenivas $\mathrm{V}$, et al. Titers of Anti-tissue Transglutaminase Antibody Correlate Well With Severity of Villous Abnormalities in Celiac Disease. J ClinGastroenterol 2015; 49:212-217 
16. Bhattacharya M, Lomash A, Sakhuja P, Dubey AP, Kapoor S. Clinical and histopathological correlation of duodenal biopsy with IgA anti-tissue transglutaminase titers in children with Celiac disease. Indian J Gastroenterol2014 Jul; 33(4):350-4.

17. Emami MH, Karimi S, Kouhestani S, Hashemi M, Taheri H. Diagnostic accuracy of IgA anti-tissue transglutaminase in patients suspected of having coeliac disease in Iran. J Gastrointestin Liver Dis. 2008 Jun;17(2):141-6.

18. Zanini B, Magni A, Caselani F, Lanzarotto F, Carabellese N, VillanacciV,et al., High tissue-transglutaminase antibody level predicts small intestinal villous atrophy in adult patients at high risk of Celiac disease. Dig Liver Dis 2012; 44: 280-5.
19. Fernández ML, Vivas S, Ruiz de Morales JM, Marugan JM. Usefulness of anti-transglutaminase antibodies in the diagnosis of Celiac disease.GastroenterolHepatol 2005; 28: 437-40.

20. Abrams JA, Brar P, Diamond B, Rotterdam H, Green PH. Utility in clinical practice of immunoglobulin a anti-tissue transglutaminase antibody for the diagnosis of Celiac disease. ClinGastroenterolHepatol 2006; 4: 726-730.

21. Vivas S, Ruiz de Morales JG, Riestra S, Arias L, Fuentes D, Alvarez N, et al. Duodenal biopsy may be avoided when high transglutaminase antibody titers are present.World J Gastroenterol 2009; 15:4775-80.

*Corresponding author:

Dr Benjith Paul, Department of Pathology, Command Hospital Air Force, Bangalore- 560007

Phone: +91 9633306256

Email: address: benjithpaulk@gmail.com

Financial or other Competing Interests: None. 